\title{
Methods for optimization of hard coal fly ash quality. Chances and risks in Central and Eastern Europe
}

\author{
P. NOWAK ${ }^{12^{*}}$, T. BAJDA ${ }^{1}$ \\ ${ }^{1}$ PGE Energia Ciepła S.A., ul. Złota 59, 00-120 Warszawa, \\ Poland, (*correspondence: paulina-nowak@gkpge.pl) \\ ${ }^{2}$ AGH University of Science and Technology, Faculty of \\ Geology, Geophysics and Environmental Protection, al. \\ A. Mickiewicza 30, 30-059 Kraków, Poland, \\ (bajda@agh.edu.pl)
}

The main objective of this study was to compare different methods of hard coal fly ash fineness optimization. Fineness is one of the key quality parameters required by construction industry, the biggest field of fly ash utilization. Fly ash, that not meet the requirements of construction industry, is harder to utilize, and in many occasion must be stored in landfills which has a considerable environmental impact. Analyzed optimization methods include selection of fuel and combustion process parameters, selective collection and postcombustion, air classification. Based on conducted works, air classification was selected as optimal method and tested using raw fly ash from different production facilities. Irrespective of fineness of raw material it was possible to obtain several, designed material fractions, from ultra-fine to ultra-thick, which were all tested according to European "Fly ash for concrete" standard. Due to its physico-chemical properties, all of the fractions can be used in different applications, which potentially reduce the amount of stored material.

Additionally, risks related to current development paths observed in the electricity and heat production sector were analyzed. One of the main detected risk was ash contamination with ammonia from flue gas denitrification process. As part of the study, a number of ash samples were tested, using X-ray diffraction (XRD), X-ray fluorescence (XRF) and scanning electron microscopy (SEM) to determine most common ammonia form. In addition to extensively described in the literature ammonium sulfate $\left(\left(\mathrm{NH}_{4}\right)_{2} \mathrm{SO}_{4}\right)$ and ammonium bisulfate $\left(\mathrm{NH}_{4} \mathrm{HSO}_{4}\right)$, significant amounts of ammonium chloride $\left(\mathrm{NH}_{4} \mathrm{Cl}\right)$ were also found in some samples. $\mathrm{NH}_{4} \mathrm{Cl}$ is very untypical and problematic substance that can cause several technical malfunctions during post combustion processes.

We gratefully acknowledge the support of Polish Ministry of Science and Higher Education provided in Implementation PhD Program. 